\title{
Shifts in the food of Nile tilapia, Oreochromis niloticus (L.) in Lake Victoria, Kenya
}

\author{
M. Njiru ${ }^{1 *}$, J. B. Okeyo-Owuor ${ }^{2}$, M. Muchiri ${ }^{3}$ and I. G. Cowx ${ }^{4}$ \\ ${ }^{1}$ Kenya Marine and Fisheries Research Institute (KMFRI), PO Box 1881, Kisumu City, Kenya, ${ }^{2}$ School of Environmental Studies (SES), Moi \\ University, PO Box 3900, Eldoret, Kenya, ${ }^{3}$ Fisheries Department, Moi University, PO Box 3900, Eldoret, Kenya and ${ }^{4}$ University of Hull \\ International Fisheries Institute, Hull HU6 7EX, U.K.
}

\begin{abstract}
Studies of the food of introduced Nile tilapia, Oreochromis niloticus (L.) with respect to size, habitat and season were conducted between November 1998 and October 2000 in Kenyan waters of Lake Victoria. Stomach contents of 1980 specimens collected by demersal trawl and seining were analysed. Nile tilapia originally known to be herbivorous, feeding mostly on algae has diversified its diet to include insects, fish, algae and plant materials. The major diet of fish $<5 \mathrm{~cm}$ total length was zooplankton whereas bigger fish included a wider range of food items in their diet. There was spatial variation in diet with insects and algae dominating in the gulf and open water habitats respectively. There was no seasonal variation in the food items ingested and diel feeding regime indicated that $O$. niloticus is a diurnal feeder. The shift in diet could be due to ecological and environmental changes in Lake Victoria, which have been associated with changes in composition and diversity of fish and invertebrate fauna, emergence and dominance of different flora including water hyacinth Eichhornia crassipes (Mart.) Solms-Laub., and algae communities. The feeding habit of O. niloticus is discussed in the context of changes occurring in the lake.
\end{abstract}

Key words: diet, ecosystem changes, insectivorous, Nile perch, haplochromines, herbivorous

\section{Résumé}

Entre novembre 1998 et octobre 2000, on a réalisé des études sur la nourriture des tilapias, Oreochromis niloticus (L.), introduits dans les eaux kenyanes du lac Victoria, en fonction de leur taille, de l'habitat et de la saison. Les contenus stomacaux de 1980 spécimens récoltés par la pêche du fond au chalut et à la senne ont été analysés. Le tilapia, connu au départ comme un herbivore, se nour-

*Correspondence: Tel.: 254-57-21461; E-mail: rmnjiru2002@ yahoo.com rissant principalement d'algues, a diversifié son régime alimentaire pour y inclure des insectes, des poissons, des algues et d'autres matières végétales. La plus grande partie du régime des poissons de moins de $5 \mathrm{~cm}$ de longueur totale se composait de zooplancton, alors que les plus gros poissons y incluaient une gamme plus variée d'aliments. Il y avait une variation spatiale du régime, les insectes et les algues dominant respectivement dans le golfe et dans les eaux ouvertes. Il n'y avait pas de variation saisonnière des aliments ingérés, et le régime quotidien indique qu' O. niloticus se nourrit de jour. Les changements de régime alimentaire pourraient être dus à des changements écologiques et environnementaux dans le lac Victoria, qui pourraient eux-mêmes avoir été associés à des changements de la composition et de la diversité de la faune piscicole et invertébrée, à l'émergence et à la dominance d'une certaine flore, y compris la jacinthe d'eau, Eichhornia crassipes (Mart.) Solms-Laub., et de communautés d'algues. Les habitudes alimentaires d' O. niloticus sont discutées dans le contexte des changements survenus dans le lac.

\section{Introduction}

Nile tilapia, Oreochromis niloticus (L.) is widely distributed in Africa and many parts of the world (Trewavas, 1983). It was introduced into Lake Victoria in the 1950s together with other tilapiines like O. leucostictus (Graham), Tilapia zillii (Gervais) and T. rendalii (Boulenger) (Welcomme, 1967; Trewavas, 1983). In 1960, O. niloticus constituted $<1 \%$ of commercial catch landings (Welcomme, 1967), rising to $7 \%$ by 1999 (Othina \& Tweddle, 1999). Currently O. niloticus is the most important tilapiine, whereas the native species of O. variabilis (Boulenger) and O. esculentus (Graham) have largely disappeared (Witte \& Van densen, 1995). Nile tilapia now constitutes the third most important commercial fishery in the Kenyan portion of Lake Victoria, after Nile perch, Lates niloticus (L.) and a native cyprinid, Rastrineobola 
argentea (Pellegrin) (Njiru et al., 2002). The dominance of $O$. niloticus over other tilapiines in the lake is attributed to several factors including high fecundity and fast growth rates (Welcomme, 1967; Balirwa, 1998).

Observations made in lakes and rivers where O. niloticus occurs shows the species to prefer algae and plant material in its diet, but it ingests a great variety of foods (LoweMcConnell, 1958; Moriarty \& Moriarty, 1973; Ochumba \& Manyala, 1992; Getabu, 1994; Balirwa, 1998). The species tends to feed on bottom deposits derived from the planktonic rain and other sources, and gains nutritive value from organic particles and other organisms, which cover their surface (Moriarty \& Moriarty, 1973). In the Nyanza Gulf of Lake Victoria, O. niloticus was observed to feed primarily on blue green algae and diatoms, desmids and green algae (Getabu, 1994).

In recent years, the fish community structure and ecosystem dynamics of the lake have changed, but no studies have been carried out to assess whether the fishes have altered their diets in the Kenyan waters of Lake Victoria. The aim of this study was to determine whether O. niloticus has changed its feeding habits with ecosystem and fish community structure changes in the lake.

\section{Materials and methods}

\section{Study area}

The Kenyan part of Lake Victoria comprises the main lake (open waters) and semi-enclosed Nyanza Gulf also known as Kavirondo or Winam Gulf (Fig. 1). The main geographical, hydrological and physical characteristics of Lake Victoria and Nyanza Gulf have been summarized by Crul (1995). Nyanza Gulf lies within the equatorial region. The water temperature and solar radiation are relatively constant throughout the year (mean value of $22 \pm 3^{\circ} \mathrm{C}$ and

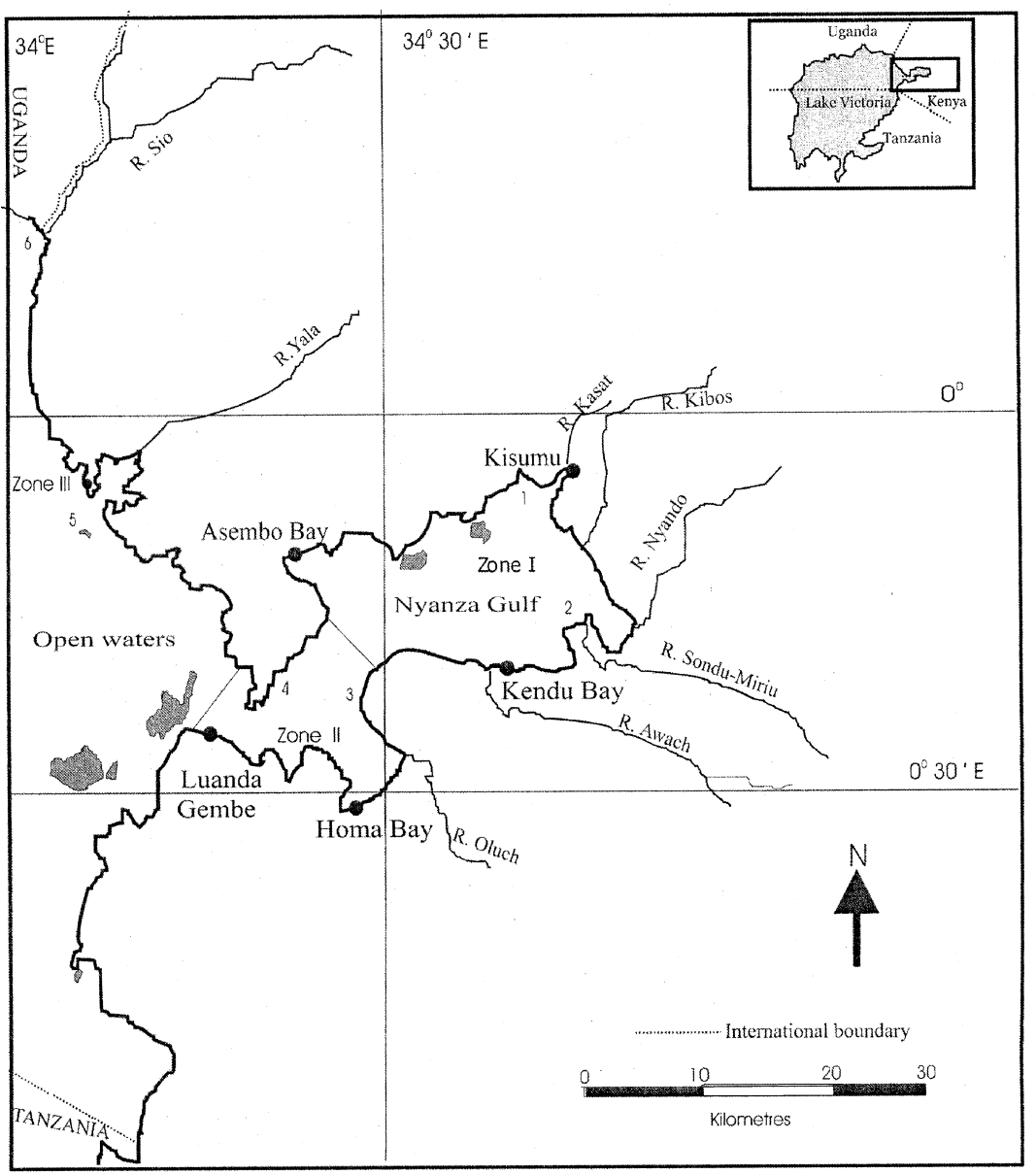

Fig 1 Map of Lake Victoria, Kenya, showing sampling areas 
$1200 \pm 140 \mathrm{ME} \mathrm{M}^{-1} \mathrm{~S}^{-1}$ ). There are two main rainy seasons, the long rains occurring from March to May and short rains from November to December.

\section{Sampling procedures}

The Kenyan part of Lake Victoria was divided into three zones (Fig. 1). Zone I is shallow (3-4 m), has the highest number of rivers and covers the inshore Nyanza Gulf waters. Zone II is deep (10-20 m) and covers the offshore Nyanza Gulf waters. Zone III is shallow (5-6 m) covering the inshore open lake. Samples of $O$. niloticus were obtained by bottom trawl (head rope $22.6 \mathrm{~m}$, codend mesh size $24.5 \mathrm{~mm}$ ) and mosquito seine ( $5 \mathrm{~mm}$ ) during November 1998 to October 2000. Trawls were conducted monthly except when circumstances could not permit. Seining caught most fish below $10 \mathrm{~cm}$. Immediately after capture total length $(\mathrm{TL}, \mathrm{cm})$ of fish was measured to the nearest centimetre and gut contents removed and preserved in $4 \%$ formalin. The gut contents were analysed using a modified point method according to Hynes (1950) as reviewed by Hyslop (1980). Each stomach was awarded an index of fullness from 0 to 20; empty stomach scored 0; a quarter full 5; half full 10; threequarter full 15 and full 20. In the laboratory, stomach contents were emptied into a Petri dish and food items were sorted into categories using a binocular $(\times 50)$ microscope. Each category was assigned a number of points proportional to the estimated contribution. The importance of each food category was expressed as a percentage by dividing the total points awarded to all food types into number of points awarded to the food type in question. Stomach contents for each $5 \mathrm{~cm}$ length class were assessed separately.

To establish when the fish fed, a 24-h sampling regime was conducted every $2 \mathrm{~h}$ by seining. Individual fish caught were weighed $(\mathrm{g})$ and measured $(\mathrm{TL}, \mathrm{cm})$. The stomachs were opened up and the contents weighed $(\mathrm{g})$ using an electronic balance. Stomach fullness (SF) were expressed as percentage of fish viz.

$\mathrm{SF}=\mathrm{SC} /$ fish weight $(\mathrm{g}) \times 100$,

where $\mathrm{SC}=$ stomach contents $(\mathrm{g})$.

\section{Results}

\section{Diet composition}

During the period November 1998 to October 2000 the gut contents of 1980 Nile tilapia, O. niloticus, were

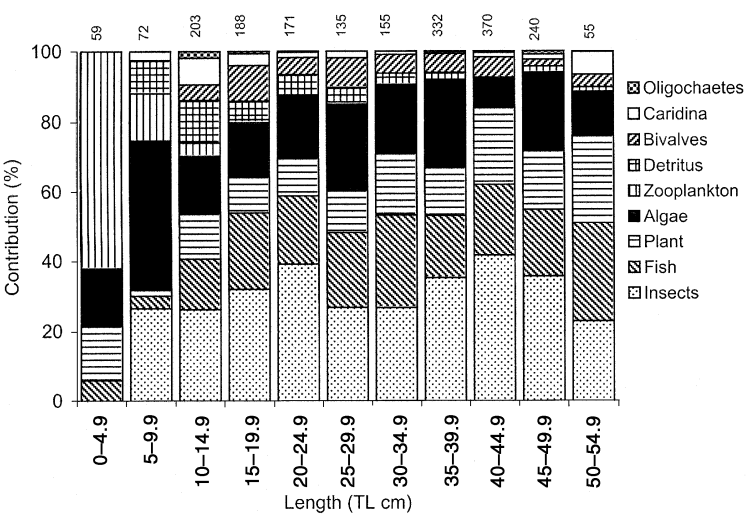

Fig 2 Food of Oreochromis niloticus of different length from Lake Victoria, Kenya. Numbers above columns indicate sample size

analyzed. The fish examined ranged from 1.6 to $55.5 \mathrm{~cm}$ TL. Insects, particularly Povilla adusta (Návas), fish ( $R$. argentea), algae and plant material were the most important food types, with fish of all sizes including them in their diet (Fig. 2). Insect constituted $42.6 \%$, of which unidentified insect remains were $21.5 \%, P$. adusta $10.8 \%$, Trichoptera $8.1 \%$, Odonata $1.1 \%$ and Chironomid $1.1 \%$. Fish constituted $18.1 \%$, of which unidentified fish remains were $11.9 \%, R$. argentea $4.7 \%$, haplochromines $0.9 \%$ and juvenile Nile perch $0.5 \%$. Algae and plant constituted $14.3 \%$ and $12.5 \%$, respectively, of the entire diet fed upon by O. niloticus. Other invertebrates included zooplankton (Cladocera, Copepoda), which constituted 4.8\%, Caridina nilotica (Roux) 0.6\%, and oligochaetes $0.3 \%$ of the total food items ingested by 0 . niloticus. Bivalves and detritus contributed 3.6\% and $3.1 \%$, respectively, of the food items in the tilapia gut.

Food in relation to fish size

A change in the diet with increasing size was apparent, with all size classes consuming all the important food items (Fig. 2). Zooplankton was the major food of O. niloticus under $5 \mathrm{~cm}$ TL, and was of little importance to fish larger than $10 \mathrm{~cm}$ TL. Insects were also of little importance to the diet of small Nile tilapia $(<5 \mathrm{~cm})$, but were major food items of larger fish. Algae, fish and plant material were consistently important to all size groups. Fish $<10 \mathrm{~cm}$ did not consume bivalves, $C$. nilotica or oligochaetes. Only one fish of $55.5 \mathrm{~cm}$ TL was caught with gut full of P. adusta. 
Spatial variation in diet composition

There was spatial variation in the composition of the food items consumed by Nile tilapia in Lake Victoria, Kenya. Insects dominated tilapia diet in the inshore $(51.1 \%)$ and offshore gulf (42.8\%) of the lake. The other important food items in the gulf were fish and plant material. In the inshore open waters zone, the important food item was algae $(32.7 \%)$ followed by fish $(26.8 \%)$ and insects $(24.4 \%)$. Detritus $(6.0 \%)$ constituted a significant proportion of tilapia food in the inshore gulf and bivalves $(6.8 \%)$ featured more in the offshore zone. Zooplankton was consumed more in the inshore zone while oligochaetes and Huridinea were rarely ingested in any of the zones. Chi-square test revealed significant difference between the ingested insects $\left(\chi^{2}=9.47, P<0.05\right)$, plant $\left(\chi^{2}=7.00\right.$, $P<0.05), \quad$ algae $\left(\chi^{2}=19.3, \quad P<0.05\right), \quad$ detritus $\left(\chi^{2}=6.21, \quad P<0.05\right)$ and zooplankton $\left(\chi^{2}=10.3\right.$, $P<0.05)$ in the three zones. No significant spatial variation was detected between the other food items.

Further analyses by station revealed that insects were the most important food items except in station 6 where algae dominated (Table 1). Fish ingested in all the stations was dominated by $R$. argentea with tilapia at stations 5 and 6 having no haplochromines and Nile perch in its diet. Plant and detritus were consumed more in the gulf stations, while Caridina was frequently eaten at stations 2 and 5. Bivalves featured more in stations 3 and 4 while oligochaetes and Huridinea were rarely consumed.

\section{Seasonal variation in diet composition}

The monthly variation in the composition of the food ingested by $O$. niloticus by zones showed insects to be the most important annually in the inshore (51.1\%) and offshore $(42.8 \%)$ gulf while algae dominated in the inshore $(32.7 \%)$ open waters. The other important food items annually in all the zones were fish and plant material. Fish contributed $17 \%, 16.1 \%$ and $26.8 \%$ of the total diet of Nile tilapia in zones I, II and III respectively. Contribution of plant material to the diet of O. niloticus varied from $12.3 \%$, $15.1 \%$ to $3.6 \%$ in zones I, II and III respectively. Bivalves were ingested by tilapia in all the months in zone II and occasionally taken in the other zones. Zooplankton, Cari-

\begin{tabular}{|c|c|c|c|c|c|c|}
\hline \multirow[b]{2}{*}{ Food item } & \multicolumn{2}{|c|}{ Zone I } & \multicolumn{2}{|c|}{ Zone II } & \multicolumn{2}{|c|}{ Zone III } \\
\hline & $1^{*}$ & 2 & 3 & 4 & 5 & 6 \\
\hline Insect remains & 8.2 & 34.3 & 26.1 & 19.4 & 23.5 & 0.6 \\
\hline Chironomid & & 0.2 & 0.1 & 2.3 & 4.5 & \\
\hline Trichoptera & 10.2 & 14.4 & 6.4 & 8.3 & 3.6 & 0.6 \\
\hline Povilla & 28.6 & 6.7 & 8.0 & 11.1 & & 3.3 \\
\hline Odonata & 0.1 & & 3.1 & 0.1 & & \\
\hline Total insects & 47.1 & 55.6 & 43.7 & 41.2 & 31.6 & 4.5 \\
\hline Fish remains & 13.8 & 10.4 & 9.9 & 10.6 & 17.4 & 19.1 \\
\hline R. argentea & 0.9 & 5.8 & 5.0 & 3.3 & 8.2 & 11.0 \\
\hline Haplochromines & 1.8 & 1.5 & 0.7 & 1.1 & & \\
\hline Nile Perch & & 0.5 & 1.0 & 0.2 & & \\
\hline Total fish & 16.5 & 18.2 & 16.6 & 15.2 & 25.6 & 30.1 \\
\hline Plant & 17.5 & 6.2 & 11.8 & 20.4 & 1.3 & 9.8 \\
\hline Algae & 6.3 & 9.9 & 13.0 & 12.5 & 25.8 & 51.6 \\
\hline Detritus & 8.0 & 3.9 & 3.6 & & & 0.8 \\
\hline Cladocera & 1.9 & 0.1 & 0.4 & 1.0 & 0.2 & \\
\hline Copepoda & 0.4 & & & 0.1 & 8.7 & \\
\hline Zooplankton & 2.3 & 0.1 & 0.4 & 1.1 & 8.9 & \\
\hline Bivalves & & & 7.9 & 5.0 & 0.4 & \\
\hline Caridina & 2.3 & 6.0 & 3.0 & 3.0 & 6.4 & 2.4 \\
\hline Oligochaetes & & & & 1.3 & & \\
\hline Huridinea & & 0.2 & & & & 0.7 \\
\hline
\end{tabular}

Table 1 Percentage contribution of various food items in the gut of O. niloticus from various zones in Lake Victoria

*Station number. 


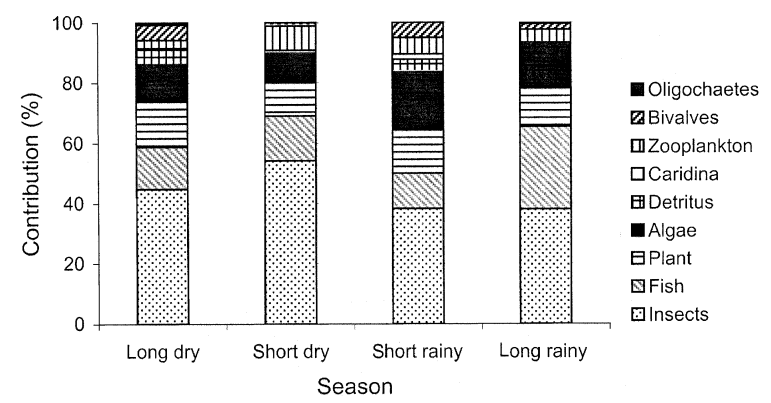

Fig 3 Seasonal variation of food items ingested by O. niloticus in Lake Victoria, Kenya

dina, oligochaetes and Huridinea were sporadically taken in all the zones annually.

The seasonal variation in the diet of $O$. niloticus shows the highest $(54.3 \%$ ) consumption of insects occurred in the short dry season (Fig. 3). Nile tilapia ingested more plant, detritus, bivalves and oligochaetes in the long dry season whereas fish was mainly consumed in the long rainy season. Most algae and Caridina were ingested during the short rainy season while zooplankton was mainly consumed in the short dry season. A chi-square test detected no significant seasonal differences between the food items ingested by $O$. niloticus.

\section{Diel feeding rhythm}

A 24-h feeding study showed O. niloticus feeds mostly during the day and very little food is ingested at night (Fig. 4). The daily feeding regime has two peaks, one around 11.00 and the other around 17.00 hours. Food ingested starts declining after dusk (19.00 hours) reaching

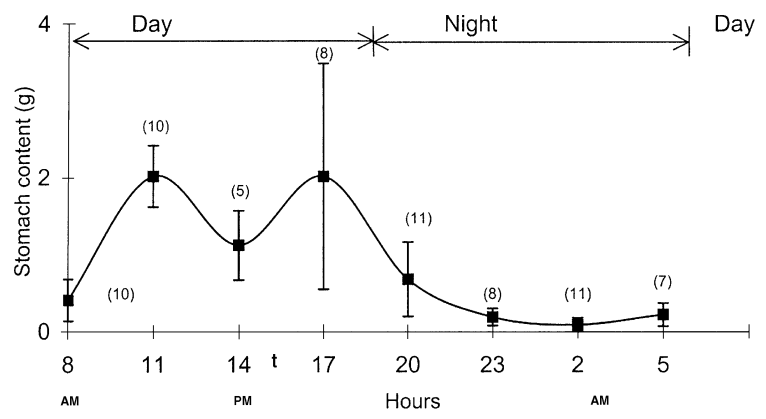

Fig 4 Diel feeding regime of O. niloticus from Lake Victoria, Kenya. Vertical lines indicate the mean \pm SD. Figures in parentheses indicate sample size the lowest level at 02.00 hours in the morning. The stomach contents start to increase again at 05.00 hours.

\section{Discussion}

Despite its wide ecological tolerance (Lowe-McConnell, 1958; Balirwa, 1992), Nile tilapia in Lake Victoria is depicted as retaining food habits similar to those of the indigenous tilapiine (O. esculentus and O. variabilis), which it replaced (Trewavas, 1983; Witte \& Van densen, 1995). Nile tilapia is described as primarily herbivorous, feeding mostly on phytoplankton (Moriarty \& Moriarty, 1973; Getabu, 1994).

Nile tilapia exhibited a trophic shift between 1994 and 1998-2000 from predominantly herbivorous (mainly algae) to a more diversified diet (Fig. 5). Getabu (1994) observed $O$. niloticus to feed mainly on algae $(87 \%)$ and aquatic invertebrates (13\%) in the Kenyan waters of Lake Victoria. The invertebrates consumed in 1994 included mainly Copepoda, Cladocera and Rotifera. Overall the most notable change in $O$. niloticus diet was the dramatic decrease in the importance of algae and the increased importance of fish, plants and invertebrates (mainly insects and bivalves). The dietary shift in Kenyan waters of Lake Victoria was coincident with a decline of non-cichlids (cat fishes, lungfish) and cichlids (haplochromines) (OgutuOhwayo, 1990; Othina \& Tweddle, 1999; Njiru et al., 2002). The reduction in fish species in Lake Victoria is attributed to various factors, among them, invasion of predatory L. niloticus and overexploitation. The change in O. niloticus feeding behaviour could be attributed to its

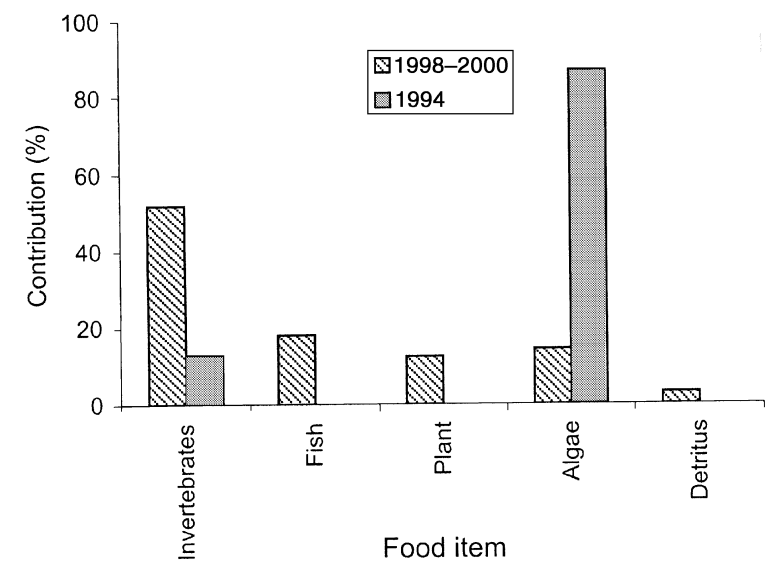

Fig 5 Contribution of the main food items in the gut of O. niloticus in Kenyan waters of Lake Victoria in 1994 and 1998-2000 
niche breadth. The species is filling niches previously occupied by various cichlids and non-cichlids which no longer exist in the lake (Ogutu-Ohwayo, 1990; Witte \& Van densen, 1995; Balirwa, 1998). The reduction in fish groups previously occurring in the lake may have led to an increase in food resources and a reduction in competition, an opportunity that has been utilized by $O$. niloticus.

The dominance of insects in the diet of $O$. niloticus could be attributed to infestation of the lake by floating macrophytes especially water hyacinth, which provides more habitats for insects (Muli, Mavuti \& Ntiba, 2000). Except for a fringe of papyrus and reeds, floating and submerged macrophytes are rare in Lake Victoria (Balirwa, 1998). Insects were more important in the Nyanza Gulf compared with inshore open waters. Nyanza Gulf sheltered from strong winds had more floating macrophyte infestation. The inshore open water stations experience stronger waves making it difficult for floating macrophytes to be stationary in the area for a long time. The availability of more macrophytes in the gulf may account for more insects being ingested here than in the inshore open waters. The dietary importance of algae in the inshore open waters may be due to low availability of invertebrates (due to fewer macrophytes).

Bivalves (which were not reported in the diet of tilapia in 1994) composed a significant proportion of tilapia diet in 1998-2000 with the highest ingestion in the offshore gulf $(6.8 \%)$ and inshore open waters $(5.3 \%)$ in this study. The high consumption of molluscs in the tilapia diet could be the result of the increase of molluscs in the lake, coincident with loss of several molluscivorous haplochromines, which were more abundant in the deeper waters of Lake Victoria (Olowo \& Chapman, 1999).

The increase in fish (mainly $R$. argentea) in O. niloticus diet could be attributed to a reduction of in numbers its main predator the Nile perch. In contrast to most of the native species the pelagic cyprinid $R$. argentea has increased in Lake Victoria (Witte et al., 1992; Othina \& Tweddle, 1999). The R. argentea habitat overlap with Nile perch is small and the predation pressure exerted by the perch was more on zooplanktivorous haplochromines than $R$. argentea. Higher predation pressure on haplochromines could have led to competitive release (food) and this might have benefited $R$. argentea. Thus the increase in $R$. argentea in tilapia diet could have been due to its availability compared with haplochromines and juvenile perch.

The monthly variation in the feeding pattern of O. niloticus showed no obvious trends. The abundance of most food items fluctuated between months, probably in response to changes in availability of food items in the environment. The monthly change in diet observed may also be related to relative abundance and convenient size of food items in the lake. When the monthly data was grouped into seasons no variation was detected in the diet ingested by O. niloticus. Coulter (1977) reported that in many fishes selection of prey is governed by availability rather than preference for a particular species, which could be the case for O. niloticus in Lake Victoria. Ogari \& Dadzie (1988) noted a similar pattern in L. niloticus an introduced species in Lake Victoria, which switched from haplochromine cichlids to more abundant zooplankton crustacean (C. niloticus) when the former declined.

Predators are also known to maximize the overall rate of uptake of nutrients if they eat the most profitable food and they tend to ignore less valuable food when more profitable ones are abundant (Krebs, 1979). The optimal diet model predicts specialization on the more profitable prey when they are abundant, and selectivity increases as the more valuable prey become more abundant (Krebs, 1979). Satiated predators become less selective than somewhat less well fed ones. To predators that take both animal and plant material a balanced diet may be more valuable. In comparison with other food items, algae are low in energy and other nutrients, and difficult to digest due to their strong cell walls and high content of indigestible material (Hay, Kappel \& Fenical, 1994). The Nile tilapia could be opting for the more profitable animal protein source for nutrition in invertebrates and fish remains instead of algae. The fish could also be maximizing nutritional sources by taking both plant and animal materials.

The dominance of zooplankton in O. niloticus $<5 \mathrm{~cm}$ TL is in agreement with Moriarty \& Moriarty (1973). Small fish $(0-4.9 \mathrm{~cm})$ did not ingest insects, $C$. nilotica, bivalves or oligochaetes probably because of their smaller mouth gape. Getabu (1994) made similar observations, whereby the percentage occurrence of invertebrates in O. niloticus diet increased with increase in fish size. A variety of the diet consumed by $O$. niloticus within various size groups could be due to reduced competition for food. It has also been hypothesized that because juvenile fish have higher mass specific protein demand as a consequence of higher specific growth rate and greater mass specific metabolism, they may not satisfy their demand by consuming a herbivorous diet. Small fish may be forced to consume animal prey, which have greater content of protein and energy per unit weight (Benavides, Cancino \& Ojeda, 1994). 
Diet shift has been recorded for several fish species in Lake Victoria. Wanik \& Witte (2000) report that $R$. argentea, a zooplanktivorous fish, feed on a variety of food items including prawns and chironomids. The diet of Nile perch, which was originally piscivorous now consists of C. nilotica, juvenile Nile perch and R. argentea (OgutuOhwayo, 1990). Bagrus docmak (Forsskåll) has exhibited a shift from primarily piscivorous diet dominated by haplochromines to a broader diet of invertebrates and R. argentea while Schilbe intermedius (L.), also previously piscivorous, is now insectivorous (Olowo \& Chapman, 1999). The shift in diet of Lake Victoria fish is being attributed to the impact of Lates predation and overexploitation of native fish species, which have been virtually wiped out and the subsequent ecological changes in the lake. This flexibility in diet may permit existence, albeit in reduced numbers, of Lake Victoria fishes in the rapid changing ecosystem.

From the wet weight of stomach contents, it is clear that Nile tilapia follows a diurnal feeding regime. These results concur, with Trewavas (1983) who found that feeding of $O$. niloticus in Lake George is a daytime activity, beginning a little before dawn and ending at sunset, and digestion is usually completed about $2 \mathrm{~h}$ after midnight. Moriarty \& Moriarty (1973) found O. niloticus in Lake George to have empty stomachs between 02.00 and 05.00 hours. After fish start to feed there was a steady increase in the average dry weight of stomach contents. This continues until the fish stops feeding (usually shortly before sunset), after which there is a steady decrease in the average dry weight of the stomach contents. The diurnal feeding activity could be attributed to the fact that $O$. niloticus feeds by sight.

Findings from this study are of considerable ecological significance. Nile tilapia is a highly adaptable species able to exploit new opportunities and expand its realized niche to successfully colonize new habitats (Cowx, 1998; Njiru et al., 2002). In Lake Victoria the species has widened its traditional niche exploiting algal food resources towards an insectivorous feeding mode. These niches were probably vacated by the disappearance of the haplochromines. These results are comparable with Balirwa (1998) who found $O$. niloticus to feed on a variety of food items, with plant material and insects dominating. The sampling (1995-97) was during water hyacinth invasion in Ugandan waters of Lake Victoria. The results also suggest that O. niloticus may continue to expand its niche until the lake ecosystem stabilizes, although overfishing and ecosystem degradation may lead to further instability in the lake ecology with unknown consequences. It could also be important to use stable isotope technique to discern the proportions of the food items ingested by tilapia if they are assimilated and utilized for energy and growth.

\section{Acknowledgements}

The survey was funded by the European Union Lake Victoria Fisheries Research Project (Ref: ACP - RPR 227) under the co-ordination of Martin van Der Knaap. Our gratitude goes to all the research vessel crew who in one way or the other helped in data collection. Thanks to Dr E. Okemwa, J. Muli, D. Tweddle, J. Manyala for their help.

\section{References}

BALIRWA, J.S. (1992) The evolution of the fishery of Oreochromis niloticus (Pisces: Cichlidae) in Lake Victoria. Hydrobiologia 232, 85-89.

BALIRWA, J.S. (1998) Lake Victoria wetlands and the ecology of the Nile tilapia, Oreochromis niloticus (L.). PhD thesis, University of Wageningen, A.A. Balkema, Rotterdam.

Benavides, A.G., Cancino, J.M. \& OJeDA, F.P. (1994) Ontogenetic change in gut dimensions and microalgal digestibility in the marine herbivorous fish, Aplodactylus punctatus. Funct. Ecol. 8, 46-51.

Coulter, G.W. (1977) The biology of Lates species (Nile perch) in Lake Tanganyika and the status of the pelagic fishery for Lates species and Laccolites stappersii (Blgr.). J. Fish Biol. 9, 235-259.

Cowx, I.G. (1998) Stocking and Introduction of Fish. Fishing News Books, Blackwell Science, Oxford.

CRUL, R.C.M. (1995) Limnology and Hydrology of Lake Victoria. UNESCO/IHP-IV Project M-5.1. UNSECO Publishing, Paris.

Getabu, A. (1994) A comparative study on the feeding habits of Oreochromis niloticus in Nyanza Gulf, Lake Victoria and Sewage ponds. In: Proceedings of the Second EEC Regional Seminar on Recent Trends of Research on Lake Victoria Fisheries, Kisumu, Kenya, 25-27 September, Kenya, 1992 (Eds E. OKEMWA, E. Wakwabi and A. Getabu). ICIPE Press, Nairobi, Kenya.

Hay, M.E., KAPPel, Q.E. \& Fenical, W. (1994) Synergisms in plant defenses against herbivorous: interactions of chemistry, calcification and plant quality. Ecology 75, 1714-1726.

Hynes, H.B.N. (1950) The food of freshwater sticklebacks (G. aculentus and P. pungitius) with a review of methods used in studies of the food of fishes. J. Anim. Ecol. 19, 36-58.

HYSLOP, E.J. (1980) Stomach content analysis - a review of method and their application. J. Fish Biol. 17, 411-429.

KREBS, J.B. (1979) Foraging strategies and their social significance. In: Handbook of Behavioural Neurobiology, Vol. 3 (Eds P. MARTENS and J. G. VAndenbergh). Plenum Press, New York.

LOWE-MCCONNELL, R.H. (1958) Observations on the biology of Tilapia nilotica (L.) in East Africa waters. Rev. Zool. Bot. Afr. $57,130-172$. 
Moriarty, C.M. \& Moriarty, D.J.W. (1973) Quantitative estimation of the daily ingestion of phytoplankton by Tilapia nilotica and Haplochromis nigrispinnis in Lake George, Uganda. J. Zool. Lond. 171, 15-23.

Muli, J.R., Mavuti, K.M. \& NTiBa, J.M. (2000) Macroinvertebrate fauna of water hyacinth in the Kenyan waters of Lake Victoria. Int. J. Ecol. Environ. Sci. 26, 281-302.

Njiru, M., Othina, A., Getabu, A., Tweddle, D. \& Cowx, I.G. (2002) The invasion of water hyacinth, Eichhornia crassipes Solms (Mart.), a blessing to Lake Victoria fisheries? In: Management and Ecology of Lake and Resevoirs Fisheries (Ed. I. G. Cowx). Fishing News Books, Blackwell Science, Oxford, UK.

Ochumba, P.B.O. \& MANyala, J.O. (1992) Distribution of fish along the Sondu-Miriu river of Lake Victoria, Kenya - with special reference to upstream migration, biology and yield. Aquacult. Fish. Manage. 23, 701-719.

Ogari, J. \& DADZIE, S. (1988) The biology of the Nile perch, Lates niloticus (L.), after disappearance of the haplochromine cichlids in the Nyanza Gulf of Lake Victoria (Kenya). J. Fish Biol. 32, 571-577.

Ogutu-Ohwayo, R. (1990) The decline of the native fishes of Lakes Victoria and Kyoga (East Africa) and the impact of introduced species, especially the Nile perch, Lates niloticus and the Nile tilapia, Oreochromis niloticus. Environ. Biol. Fish. 27, 81-96.

Olowo, J.P. \& ChapMan, L.J. (1999) Trophic shifts in predatory catfishes following introduction of Nile perch in Lake Victoria. Afr. J. Ecol. 37, 457-470.
Othina, A. \& TweddLe, D. (1999) The status of the artisanal fishery of Lake Victoria, Kenya, with notes on improvements to the catch data collection. In: Report on the Fourth Fisheries Data Working Group (FIDAWOG) Workshop (16-20 August 1999, Kisumu (Eds I. G. CowX and D. TwEDDLE). LVFRP/TECH/ 99/07.

Trewavas, E. (1983) Tilapiine Species of the Genera Sarotherodon, Oreochromis and Danakila. London British Museum (Natural History) Publication No. 583. Unecia Ltd., Jinja Uganda.

WANIK, J.H. \& WiTTE, J.H. (2000) Niche shift in a zooplanktivorous cyprinid from Lake Victoria after the reduction of its cichlids guild members by Nile perch. In: The Pelagic Cyprinid Rastrineobola argentea as a Crucial Link in the Disrupted Ecosystem of Lake Victoria. Dwarfs and Giants - Africa Adventure (Ed. J. H. WANINK). PhD Thesis. University of Leiden, the Netherlands.

Welcomme, R.L. (1967) Observations on the biology of introduced species of Tiliapia in Lake Victoria. Rev. Zool. Bot. Afr. 76, 249-279.

Witte, F. \& VAn Densen, L.T. (1995) Fish Stocks and Fisheries of Lake Victoria. A Handbook for Field Observations. Cardigan, Samara Publishing, Cardigan, UK.

Witte, F., Goldschmidt, T., GoudswaARd, P.C., LigTVoet Oijen, M.J.P. \& WANINK, J.H. (1992) Species extinction and concomitant ecological changes in Lake Victoria. Neth. J. Zool. 42, 214-232.

(Manuscript accepted 18 November 2003) 